Oleksii Karpishchenko,

Candidate of Economic Sciences, Professor, Professor of the Department of Economics and Business Administration, Sumy State University (Sumy, Ukraine);

Oleksandr Karpishchenko,

Candidate of Economic Sciences, Associate Professor, Associate Professor of the Department of Marketing and MIA,

Sumy State University (Sumy, Ukraine);

Tetyana Vashchenko,

Candidate of Economic Sciences, Assistant Professor of the Department of Marketing and MIA, Sumy State University (Sumy, Ukraine)

\title{
REVERSE ENGINEERING AS A KEY FOR INDUSTRY MODERNIZATION PER IMPORT SUBSTITUTION
}

The article deals with problems to control business-processes at the industrial enterprise. It is based on the import substitution of the final goods components, as an intermediate stage to the production export activation with purpose to increase technical and scientific level of the production under changeable external conditions today. Analysis and prognostication of the enterprise development vectors and source for economic and stable functioning formation prove the necessity to take into account the innovative approach while developing the business dealing strategy. One of the alternative directions to realize potential of the industrial enterprises is a variant to introduce the import substitution in the productive sphere through components import displacement from the ready production and their substitution by native ones. The reasonability to use import substitution strategy at the industrial enterprise to provide the competitive goods production and export-import operations optimization, is grounded. One proposes to use reverse engineering practice to modernize production and to increase the native goods competitiveness.

Keywords: export, import, reverse engineering, import substitution strategy, production modernization.

DOI: $10.21272 / \mathrm{mmi} .2017 .2-23$

Problem statement. Integration of Ukraine into the European economy requires the high competitive goods from industrial complex. Old productive assets and lack of investments into the technologies development block the given issue. Recently one can observe the fact that native enterprises lose great share of the home market owing to the imported goods. The market oversupplying with import, great misbalance in export and import operations, instability of the currency rate requires to make strategically significant decisions to modernize and renew business-processes inside every industrial enterprise and industry on the whole. The reason consists in the fact that industrial complex is one of the key elements in native economy and is able to produce goods with high added cost.

While studying the experience of the developed countries, one can see that activity orientation to use leading technologies, scientific and research and research and constructive investigations, productive equipment modernization and introduction of the scientific and technical progress results into industrial enterprise activity are able to lead to the stable economic growing. That's why, innovativeness and technological level growing have to be the priority directions in the native economy strategic development. As a result, the production competitiveness will be increased at the native and foreign markets, either owing to quality and technical level growth, or owing to production expenses shortening. It will partly substitute imported analogues from the native market and will assist the industrial production export amounts growing.

Analysis of recent researches and publications. Problems concerning business-processes 
optimization and improvement of the industrial enterprise management system are demonstrated in works of N.S. Illyashenko [2], Ya.A. Zhalilo [1], A.A. Masaraki [3] and others. However, under today's market conditions, classical models do not give the required result. They need to be completed with creatively different modern approaches. An import substitution is one of such directions of the strategic management. Such scientists as T. Melnyk [4], S.M. Pazizina [6], O.I. Popova [8], L.I. Fedulova [18], M.M. Yakubovsky [20] observed it. However, researchers investigate it from the viewpoint of state level and with government support $[9 ; 16]$. Nowadays there is much tension around the import substitution realization problem at the industrial enterprise, where reverse engineering takes its own place, as a precondition to introduce innovative technologies. The given problem is studied by the following scientists: T. Davenport [25], I. Prymak [10], Yu. Pshennyk [11], M. Robson, Ph. Ullah [12], A. Sosnov [15], L.M. Taranyuk [17], M. Hammer [19].

Unsolved issues as part of the problem. It is possible to take competitive position at the European market only through using of the production innovative intensive development. It is connected with production quality and production efficiency growing, however, the question concerning stages for business-processes modernizations at the enterprise, based on import substitution with reverse engineering use, has not been solved yet.

The aim of this article is research of the role and place of reverse engineering in the modernization of business processes of industrial enterprise on the basis of import substitution.

Basic materials. Nowadays the problem of business-processes modernization or renewing attracts great attention. Innovative development and production intensification are main issues while investigating the industrial enterprise strategy with non-competitive production particularly at the international market. The modernization process task is to use maximum resource base, scientific and staff potential in order to develop and to improve economy.

The industrial complex in Ukraine requires great transformations. They will allow minimizing of dependence on import. According to different data, about $20 \%-40 \%$ of the industrial goods production cost are imported components. The production modernization for their substitution is a real perspective that will impact the development of the whole native economy and will reduce dependence on import.

The import substitution is one of the major tools to protect and to develop the economy in the country. There are a lot of examples concerning those countries which used the import substitution policy with purpose to develop native enterprises and to strengthen state economy.

"Dependency theory" was a source for import substitution. It was formed in economics in the 60s of $X X$ century. The import substitution is a precondition for impact on structural shifts of the national production to optimize international trade. The given model of development appeared as a result of the countries' import dependency on the industrially developed ones. The industrial and technological dependency appeared during the post-war period under impact of the multinational corporations, which invested money into industry, oriented to the home market of the loss developed countries [30].

During 70-90-s XX century the W. Wallerstein's dependency theory was formed, based on authors' conceptions, who negatively evaluate the transnational companies activity influence in the economic intervention sphere. At the same time P. Baran confirmed that foreign capital tried to control home markets. In its turn, periphery takes up positions of the capitalistic development, but incomes from MNKs are not reinvested into the productive sphere in this country [13].

The import substitution optimizes external trade balance, stores currency reserves inside the country, and prevents from inflation and economic processes normalization at the enterprises of the home market. Supporters of the import substitution suppose that raw materials and stocks are sold at low prices and ready products are purchased at high prices. It only increases economic dependence of the country and destabilizes producers $[21 ; 24 ; 28 ; 29]$. Proper industrial sector development is not only 
one way for economy growth.

Most countries thought that during the industrial development it was better at first to strengthen home market, to protect own producer through the import substitution policy, and then to come over to the export-oriented economy model [21; 22; 28]. All countries, which have passed the industrialization stage, faced the necessity to introduce import substitution policy.

The state plan of Cuba development provided the realization of the import substitution after the private enterprises nationalization process with purpose to diversify economy in the country [26]. In order to reduce the dependence on Western countries it is necessary to provide home market mostly with consumed goods. The import substitution was clearly observed through production increase and sugar export.

Advanced emerging countries - countries of Eastern and South-Eastern Europe, Russia, Japan, Turkey fell behind the developed countries for the development phase. The competition growth at the global markets, defeat in war and risk to lose independence prompt to modernize economic processes [28]. Fast forcing way to the social and economic and technical development, which developed countries overcame during the long time, was particular for these countries.

Latin American countries also implemented import substitution [31]. In 30s-50s XX century consumer goods industry enterprises and enterprises, which produced agricultural stocks, building materials, machineries for consumer goods and wood industry, were developed. Key to success of the import substitution in this phase was protectionism policy on the part of Latin American countries government. The 50 s of the XX century is characterized with high rates in heavy industry development: chemical industry, machine building industry, metallurgy industry and metalworking.

In Mexico, Brazil and Argentina the production of technically sophisticated goods (cars, refrigeration facilities etc) was developed. Manufacturing sector increased its part in the GDP structure of the Latin American countries. During the import substitution, since 1955 to 1975, the industrial production factors were grown for $6,9 \%$ per year. At the same time in the USA - for 2,8\%, in West-European countries - for $4,8 \%$. Brazil had record high rates of the industrial production growth since 1950 to 1978, index was $8,5 \%$ per year. The economy modernization process in Brazil came with state long-term programs on the development of infrastructure and other sectors. State gave active financing for scientific and research institutes and universities. Thousands of students were sent to study abroad. During 1968-1975 GDP in Brazil was grown 2,2 times and country took eighth place in the world. Great reducing of the import and increase of the proper production was in the following spheres: cars and tractors, TV- and radio aids, engines, machineries, energetic tools, and machine building production became dominant in the export of the country.

Japan, and then South Korea, Singapore, Taiwan realized in their experience of the import substitution of technologies. Global modernization of the productive processes lead to highly qualitative production output [23].

These countries achieved success in catching-up development owing to the innovative technologies of the goods production. Incomes from their realization were directed to develop the infrastructure at the enterprises. Thus, the analyzed countries greatly reduced poverty level owing to import substitution and export extension. During twenty years of the economic processes active control in South Korea poverty level was decreased from $23 \%$ to $5 \%$, Malaysia - from $18 \%$ to $2 \%$, Indonesia from $60 \%$ to $15 \%$ [27].

India experience proved that it is possible to develop home market and to provide active support of the export for 15 years [28].

If one observes experience of the post-Soviet countries, Poland realized the import substitution policy in 80s XX century. Today such countries as Belarus, Kazakhstan and Russia face the import substitution problems in separate branches.

There are different level projects in Belarus (state, regional, some enterprises) on production of the 
import-substituting components, details, joint connections, machines etc. However, one should use the import substitution policy carefully, in order to come to the closed economy during the globalization stage. The import substitution has to develop and impel to increase the competitiveness of the native enterprises and to be the intermediate stage to the export-oriented production. Such activity will provide the producing of the high-qualitative goods, increase of profits from economic activity, sales markets extension, productive capacities modernization, and will provide optimization of the import-export operations structure in the state [5].

The global experience of import substitution realization demonstrates reasons, which supported that complicated process, namely: industrial and technological capacity development of the native enterprises, development of the home market, decrease of the impact, made by external conjuncture factors.

Import substitution has to be an intermediate stage in the process of economy restructuring in the country, to be realized to develop new industrial fields, to modernize productive processes, that will be key for export-oriented model of the economy development.

Modernization of the production with purpose to implement the import substitution strategy may take place in two ways, namely innovations investigation or their borrowing. Independent investigation of innovations requires much financing of science, researching productions creation, and mainly time, of which Ukraine is short to enter European markets. More available way, efficiency of which was confirmed many times by different countries, is to use reverse engineering.

The reverse engineering consists in the profound analysis of the foreign production prototype and in creation of analogue by modern technologies considering demands and needs of the native production that improves this or that product.

Production of goods, which are competitive at the international sales markets, is possible providing high-qualitative materials and innovative productive technologies use. The reverse engineering is a base for effective realization of the import substitution strategy.

Reverse engineering was widely used in Soviet Union during the II World War practically the whole post-war period. It allowed fast to increase technological level of different branches: from the production of new materials to radio-electronics and machine building sector. The bright example is a construction of the attack aircraft Tu-4 according to sample of the American one B-29; ballistic rocket R-1 was the same as German rocket Vau-2; cameras FED; design and partly technical filling in many autos were copied from foreign ones - Moskvich-402, 408, 412, 2141; Volga ГA3-21, 24, Zil-111, 114, 115 and others. There are various positions concerning the mentioned above factors. However, the reverse engineering furthers development of techniques and technologies.

Modern examples of the reverse engineering are China car industry goods, constructed on the basis of the well-known autos in the world. At the initial stage there were not qualitative cars with many technological drawbacks, however they become better every year and there are own investigations.

There are examples of the successful reverse engineering in modern Ukraine. In 2000s Sumy plant "Nasosenergomash" mastered the production of mechanical sealing LMP 6330-TP/070L for pumps, which run out oil products [internal information of the enterprise]. If earlier the enterprise purchased great deal of mechanical sealing, then having realized the reverse engineering, it started to purchase only friction couples, which are components of the units. Owing to it the ready production prime cost was reduced. Imported components part was also decreased and the specialists were tied up with work.

Study of the prototype, projecting and investigation of the new product will allow to substitute imported components from ready production. The key principle of the reverse engineering is from general issue to concrete point. The Fig. 1 demonstrates hierarchy of its realization principles in the productive processes at the industrial enterprise. 
О.І. Карпіщенко, О.О. Карпіщенко, Т.В. Ващенко. Реверсний інжиніринг як запорука модернізації промислового виробництва на засадах імпортозаміщення

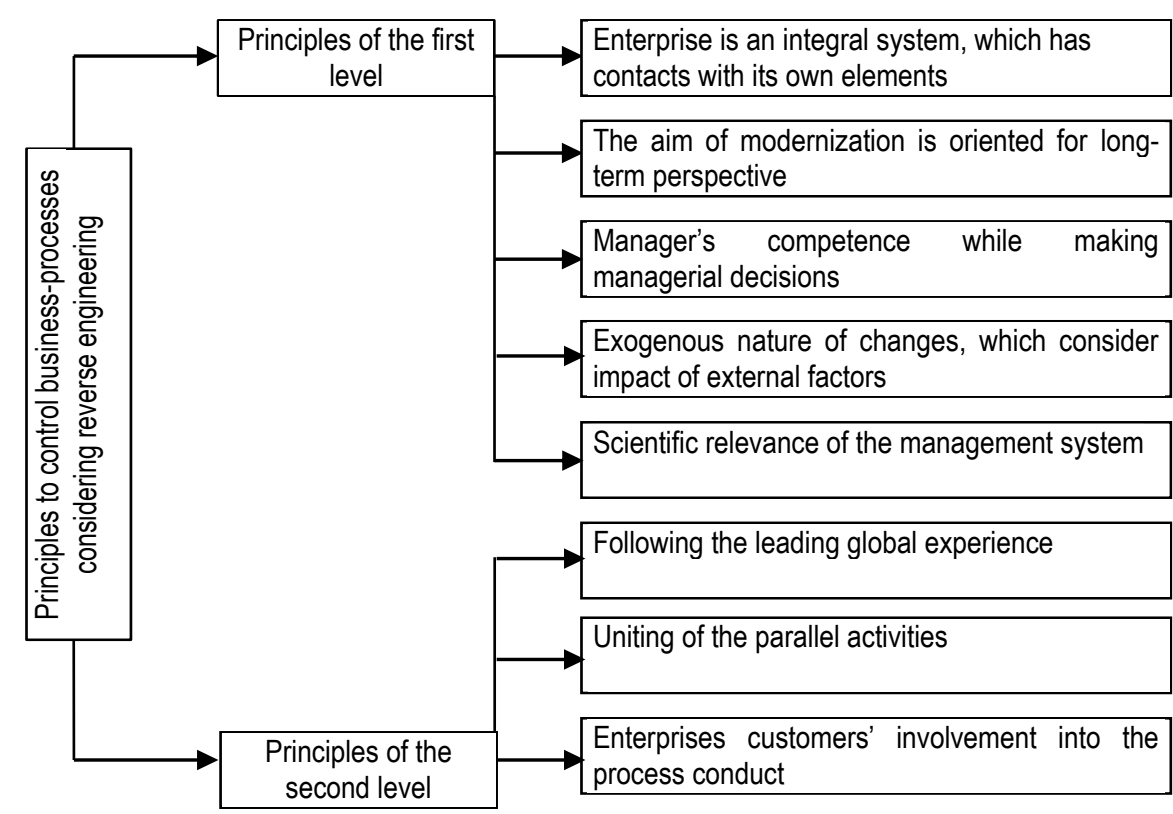

Figure 1 - Hierarchy of the reverse engineering principles realization in the productive processes at the industrial enterprise (built on the basis of $[12,19]$ )

The observed principles may be distinguished into two levels. First of all it is necessary to observe the enterprise as an integral system, which has changes, based on managerial decision making, and on the other hand - the reverse engineering practice. Other principles are also popular. However, the principles, which are presented in the fig. 1 and distinguished considering strategic vector of the development, based on import substitution. Other principles have an equivalent or little impact on the management process.

The reverse engineering using at the native industrial enterprises as a tool to realize the import substitution strategy, allows to solve one of the key problems at the state level - misbalance of the export-import operations. In September 2016 deficit of the pay balance current account was $875 \mathrm{mln}$. US dollars [7], and created the ground to modernize business-processes at the enterprises. The efficiency of such transformations consists in production prime cost reducing, main funds renewing at the enterprise, labor efficiency increase, energy efficiency technologies use, currency operations shortening. The leading technologies and modern equipment implementation will decrease labor intensity of the production process and will reduce share of the imported constituents (30-40\% of the current level). It will lead to significant decreasing of the production prime cost and producers will be less dependent on currency movement.

The import substitution strategy does not match every enterprise. The decision for its realization is made on the basis of the carried out investigations. Initially, it is necessary to analyze impact, made by factors of the external environment and to weigh up benefits, threats and possibilities, realizing some steps. The Fig. 2 shows the analysis of relevance to use import substitution strategy.

Experience of import substitution realization by Sumy plant "Nasosenergomash" can be an example. This enterprise invested money into the construction of the cast center and at the same time it could substitute components with import nature for own production. 
Розділ 4 Проблеми управління інноваційним розвитком

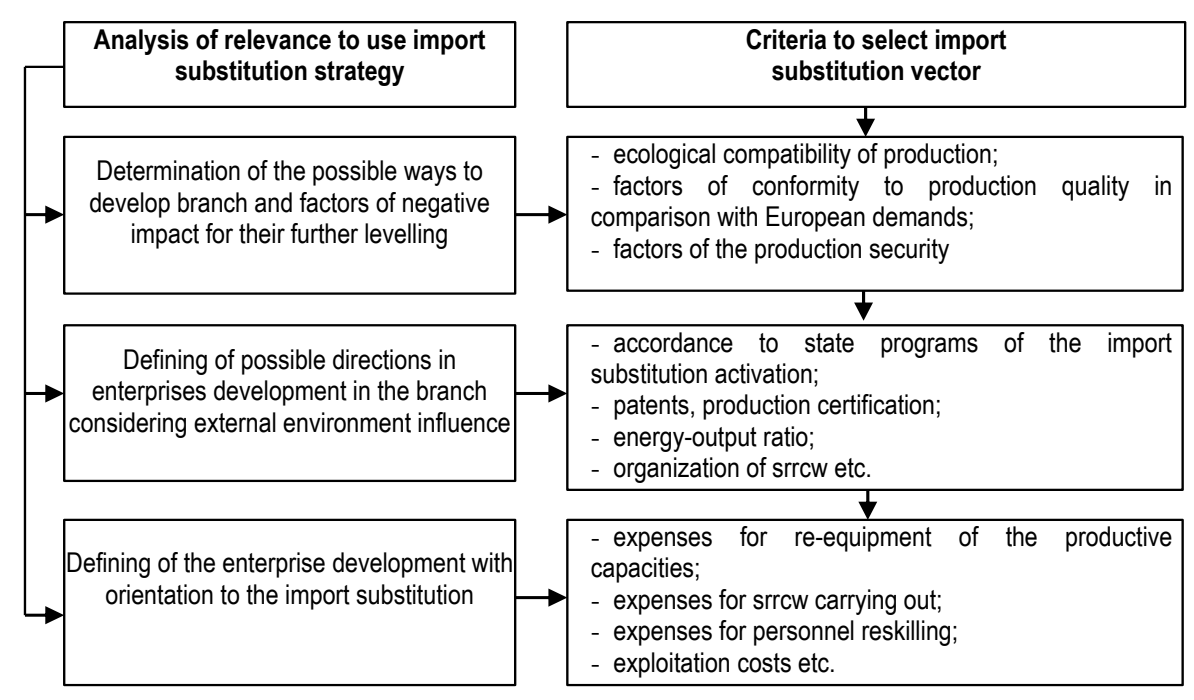

Figure 2 - Scheme of analysis on relevance to use import substitution strategy (investigated by authors)

Replacement of imported body cast for centered oil pump to produce components with capacities of own caset center allowed to reduce productive prime cost of the pump for $24 \%(170,71$ thousand UAH is cost for pump with imported components, and 137,88 - is a prime cost for components of own production). The detail became cheaper for $42 \%$, its cost was 55 thousand UAH vs 95 thousand UAH of the foreign producer. Time factor also plays an important role. The production let to shorten the term of pump production on 56 days. It helped to fulfill orders and to produce more goods more rapidly.

Setting of the production process and sales markets lead to production amounts growing almost on 200 pieces (from 761 piece to 931 pieces), and sales amounts were increased from $377 \mathrm{mln}$. UAH to $1009 \mathrm{mln}$. UAH during three years at the enterprise. The Fig. 3 represents dynamics of enterprise's activity factors.

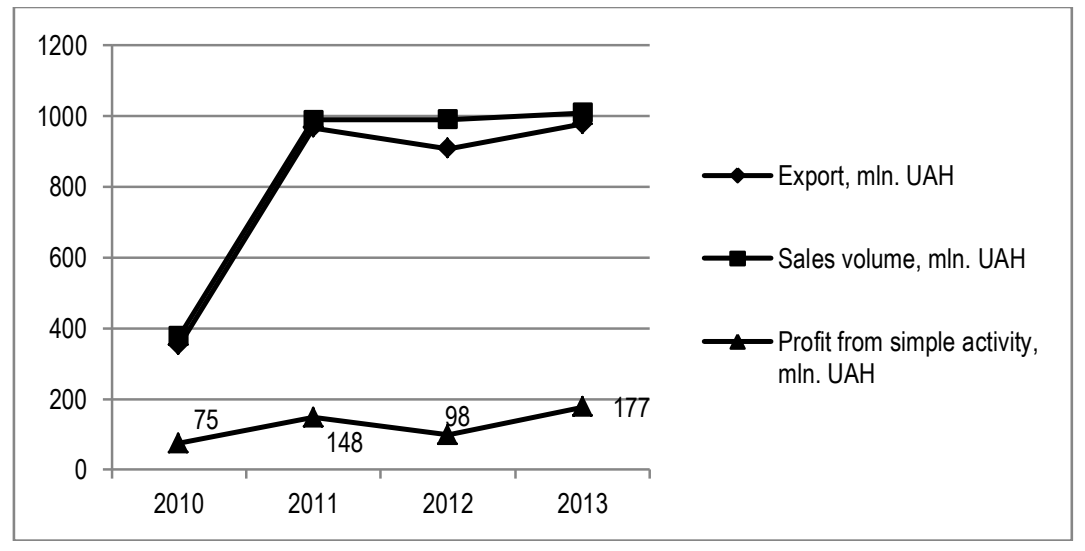

Figure 3 - Factors for realization of goods, produced by

SC "Sumy plant "Nasosenergomash", mIn. UAH (formed due to the data of the given organization) 
О.І. Карпіщенко, О.О. Карпіщенко, Т.В. Ващенко. Реверсний інжиніринг як запорука модернізації промислового виробництва на засадах імпортозаміщення

Profit is the main factor for the import substitution strategy realization. In this case it was increased during three years from $75 \mathrm{mln}$ UAH to $177 \mathrm{mln}$. UAH with investments amounting to $120 \mathrm{mln}$. UAH. Mastering of the new direction and production term reducing, enterprise's empowerment lead to export share growth from $351 \mathrm{mln}$. UAH to $977 \mathrm{mln}$. UAH. The strategic vector of the development is directed to develop export (internal information of the enterprise).

One needs several transformations of business-processes in order to realize import substitution strategy. The Fig. 4 represents structural and logic scheme of the business-processes modernization at the industrial enterprise, based on the import substitution strategy.

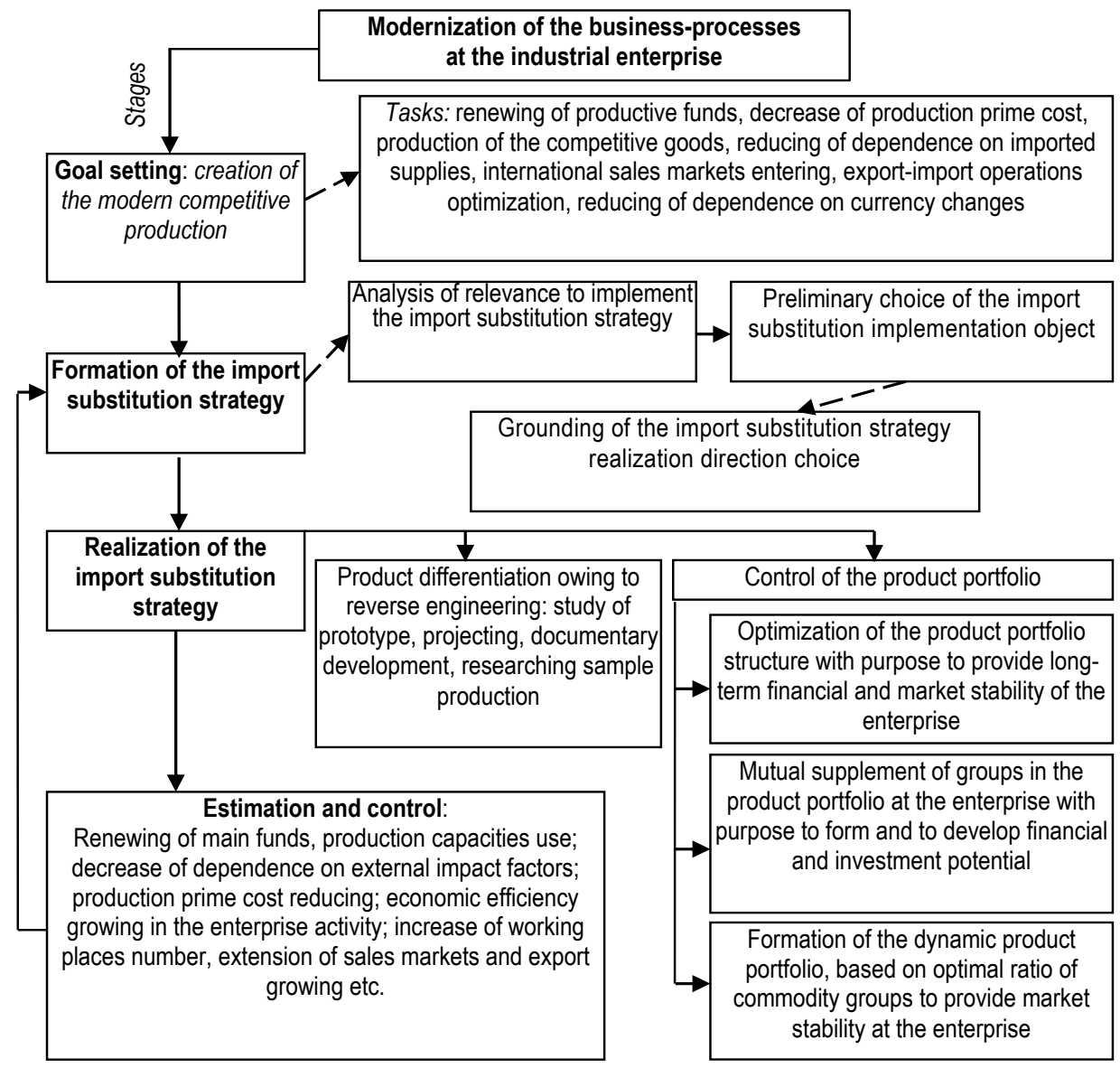

\section{Figure 4 - Structural and logical scheme of the business-processes modernization at the} industrial enterprise on the basis of import substitution (built on the basis of [14])

Import substitution makes sense in case, when a product is competitive. Thus, in order to achieve the results, it is necessary use effective cross-sectoral technologies. It is important to take into consideration the global tendencies, to carry out technologies transfer, to carry out scientific and research and constructive works every time to make profound managerial decisions. 
The goal of such global transformations for enterprise has to be not only the production of the export-oriented goods, but also investigation of high-technological service, that will lead to acceptance of scientific and research investigations at the global level. It is particular for giant enterprises. On the other hand, small enterprises have to try to be so called technological brokers between developers (applied scientists) and high technological industrial enterprises.

Introducing the import substitution strategy, commodity producers increase technical and technological level. It will be a base to enter international competitive sales markets and will allow to be actively developed and to introduce leading technologies, used by the European producers in their activity.

From the viewpoint of the European integration, the most perspective direction in the native industrial producer's development is orientation to the export development under conditions of borrowed innovations, because besides lack of innovations, the intellectual resources deficit is a great barrier to the intensive development in the national industry. That's why the international engineering practice, namely reverse engineering use in the long-term period, is the most real perspective to improve business-processes.

Conclusions and perspectives for further research. The necessity to modernize businessprocesses at the industrial enterprise is connected with great impact of both external and internal factors. The contribution of Ukrainian European integration to the global community should be pointed out. It opens international sales markets for native producers. However, on the other hand, an old productive equipment, which has not been renewed since Soviet Union times, absence of the modern technologies, used in the whole world, high dependence on imported components, lack of the intellectual resources and other factors require to make strategic decisions. It will let the enterprise to produce competitive product and in future to orient its activity to the export. The article suggests to use international practice of the reverse engineering. It is a fundament to realize import substitution strategy, particularly substitution of imported components from the ready production. The problem to organize export-oriented production and to develop actions with purpose to optimize export-import operations at the enterprise level, requires further studies.

1. Жаліло Я.А. Пріоритети політики імпортозаміщення у стратегії модернізації промисловості України / О.В. Собкевич, А.І. Сухоруков, А.В. Шевченко та ін. ; за заг. ред. Я. А. Жаліло. - К. : НІСД, 2012. - 71 с.

2. Ілляшенко Н.С. Методичний підхід щодо обірунтування доцільності реалізації інноваційних проектів / Н.С. Ілляшенко // Механізм регулювання економіки. - 2009. - № 1. - С.184-193.

3. Мазараки А.А. Теоретические и методологические основы формирования интеграционной стратегии предприятий / А.А. Мазараки, М.В. Босовская // Бизнес информ. - 2013. - № 7 - С. 299-308.

4. Мельник Т. Перспективи імпортозаміщення в Україні / Т. Мельник, К. Пугачевська // Вісник КНТЕУ. - Київ, 2015. № 2 (100). - С. 16-33.

5. Михайлова Л.І. Оцінка динаміки вектор-структури експорту продукції машинобудування вітчизняними підприємствами / Л.І. Михайлова, О.Ю. Слабоспицька // Маркетинг і менеджмент інновацій. - 2011. - №т2. - С. $164-172$.

6. Пазізіна С.М. Імпортозаміщення як чинник зрушень структури виробництва і зовнішньої торгівлі України / С.М. Пазізіна // Журнал Європейської економіки. - Тернопіль, 2012. - №т2. - С. 199-214.

7. Платіжний баланс у вересні 2016 року. - Національний банк України. - [Електронний ресурс]. - Режим доступу: http:index.minfin.com.ua.

8. Попова О.И. Импортозамещение как условие развития машиностроительного комплекса региона [Электронный ресурс] / О.И. Попова // Устойчивое развитие территорий, отраслей и производственных комплексов. - 2012. - № 3 (59). С. 39-43. - Режим доступа: http://pdt.vscc.ac.ru/file.php?module=Articles\&action=view\&file=article\&aid=2111.

9. Постанова КМУ від 12.09.2011 р. № 1130 “Про затвердження Державної програми розвитку внутрішнього виробництва" [Електронний ресурс]. - Режим доступу: http://zakon2.rada.gov.ua/laws/show/1130-2011-\%D0\%BF.

10. Примак И. Реинжиниринг: теперь без разрушений? [Електронний ресурс] / И. Примак // Управление компанией. 2007. - № 7 - Режим доступу: http://www.management.com.ua/cm/cm086.html.

11. Пшенник Ю. Какое импортозамещение нам нужно? / Ю. Пшенник // Экономическая газета. - 2007. - № 68. 
12. Робсон М. Практическое руководство по реинжинирингу бизнес-процессов / М. Робсон, Ф. Уллах ; пер. с англ. под ред. НД.Эриашвили. - М. : Аудит, ЮНИТИ, 1997. - 224 с.

13. Савчук В. Глобализація та проблеми інтеграції у цей процес постсоціалістичних країн / В. Савчук // Вісник Тернопільського національного економічного університету. - 2010. - № 5-1. - С. 22-27.

14. Ситніченко В. Стратегія розвитку машинобудування на основі системи сбалансованих показників [Електронний ресурс] / В. Ситніченко. - Режим доступу: http://www.ukrtest.com/raznoe/publikacii/11.pdf.

15. Соснов А. Феномен шпильки. инжиниринг ускорит импортозамещение [Електронний ресурс] / А. Соснов // Поиск. Газета научного сообщества. - 2015. - № 39. - Режим доступу: http://www.poisknews.ru/theme/edu/15878/.

16. Стратегія економічного та соціального розвитку України "Шляхом європейської інтеграції" на 2004-2015 роки [Електронний ресурс]. - Режим доступу: http://shron.chtyvo.org.ua/Halchynskyi_Anatolii/Stratehiia_ekonomichnoho_i_ sotsialnoho_rozvytku_Ukrainy_2004-2015_shliakhom_yevropeiskoi_intehratsii.pdf.

17. Таранюк Л.М. Науково-прикладні аспекти процесоорієнтованого управління на промислових підприємствах при проведенні реінжинірингу бізнес-процесів / Л.М. Таранюк // Маркетинг і менеджмент інновацій. - 2012. - № 1. - С. 180-189.

18. Федулова Л.І. Перспективи інноваційного розвитку промисловості України / Л.І. Федулова // Економіка і прогнозування. - 2006. - № 2. - С. 58-76.

19. Хаммер М. Реинжиниринг корпорации: Манифест революции в бизнесе/ Майкл Хаммер, Джеймс Чампи ; пер. с англ. Ю.Е.Корнилович. - М. : Манн, Иванов и Фербер, 2006. - 287с.

20. Якубовський М.М. Реструктуризація промисловості як засіб подолання імпортної залежності економіки України / М.М. Якубовський // Національне господарство України: теорія та практика управління : зб. наук. праць. - К. : Ін-т економ. та прогноз. НАН України, 2011. - С. 100-112.

21. Baer Werner. Import Substitution and Industrialization in Latin America: Experiences and Interpretations / Werner Baer /I Latin American Research Review. - 1972. - Vol. 7. - P. 95-122.

22. Blair J.P. Local economic development / J.P. Blair, M.C. Carroll. - Sage Publications, 2008

23. Bruton H. A Reconsideration of Import Substitution [Electronic resource] / H. Bruton // Journal of Economic Literature. 1998. - Vol. XXXVI. - Access mode: http://econintel.org/Cl705/BrutonlmpSubs.pdf.

24. Cardoso F.H. Dependency and Development in Latin America / F.H. Cardoso, E. Faletto ; Transl. by M. Mattingly. Berkeley : University of California Press, 1979. $-474 p$.

25. Davenport T. Process Innovation: Reengeneering Work through Information Technology / T. Davenport. - Boston , MA. : Harvard Business School Press, 1993.

26. John H. Dunning. The Prospects for Foreign Direct Investment in: Eastern Europe / P. Artisien, M. Rojec, M. Svetlicic etc. // Foreign Invetsment in Central and Eastern Europe. - New York : St. Martin's Press, 1993. - P. 16-33.

27. Narula R. Industrial Development / R. Narula, J.H. Dunning // Globalisation and Multinational Enterprises: New Realities for Developing Countries. - Oxford Development Studies, 2000. - Vol. 28(2). - P. 141-167.

28. Prebisch R. Commercial Policy in the Underdeveloped Countries / R. Prebisch // American Economic Review. -1959. Vol. 49. - P. 251-273.

29. Renato Aguilar. Latin American structuralism and exogenous factors / Aguilar Renato // Social Science Information. 1986. - Vol. 25(1). - P. 227-290

30. Saantos T. The Crisis of Development Theory and the Problem of Dependence in Latin America / T. Santos /I Modernization and Development. - 1969. - Vol. 21. - P. 42-43.

31. Street James H. Structuralism, and Dependency in Latin America / James H. Street, Dilmus D. James // Journal of Economic Issues. - 1982. - 16(3). - P. 673-689.

1. Zhalilo, Ja.A. (2012). Priorytety polityky importozamishhennja u strateghiji modernizaciji promyslovosti Ukrajiny [Policy priorities in the strategy of import substitution industrial modernization Ukraine]. Kyiv: NISS [in Ukrainian].

2. Illiashenko, N.S. (2009). Metodychnyi pidkhid shhodo obhruntuvannia dotsilinosti realizatsii innovatsiinykh proektiv [Methodical approach to study the feasibility of innovative projects]. Mekhanizm reghuljuvannja ekonomiky - Mechanism of economic regulation, 1, 184-193 [in Ukrainian].

3. Mazaraki, A.A., \& Bosovskaia, M.V. (2013). Teoreticheskie i metodologicheskie osnovy formirovaniia integracionnoj strategii predprijatij [Theoretical and methodological bases of formation of the integration strategy of the enterprises]. Biznes inform - Business Inf, 7, 299-308 [in Russian].

4. Melnyk, T., \& Pughachevska, K. (2015). Perspektyvy importozamishhennja v Ukraini [Outlook import to Ukraine]. Visnyk KNTEU - Bulletin KNTEU, 2 (100), 16-33 [in Ukrainian].

5. Mykhailova, L.I., \& Slabospytska, O.Yu. (2011). Otsinka dynamiky vektor-struktury eksportu produkcij mashynobuduvannja vitchyznjanymy pidpryjemstvamy [Evaluation of vector dynamics of exports of engineering products domestic enterprises]. Marketyngh i menedzhment innovatsii - Marketing and Management of Innovation, 2, $164-172$ [in Ukrainian].

6. Pazizina, S.M. (2012). Importozamishhennia yak chynnyk zrusheni struktury vyrobnyctva i zovnishnjoji torghivli Ukrainy [Import structure changes as a factor of production and foreign trade of Ukraine]. Zhurnal Yevropeskoi ekonomiky - Journal of the European economy, 2, 199-214 [in Ukrainian]. 
7. Platizhnyi balans u veresni 2016 roku [The balance of payments in September 2016]. (n.d.). index.minfin.com.ua. Retrived from http:index.minfin.com.ua [in Ukrainian].

8. Popova, O.I. (2012). Importozameshhenie kak uslovie razvitiia mashinostroitelnogo kompleksa regiona [Import substitution as a condition for the development of the machine-building complex of region]. Ustoichivoe razvitie territorij, otraslei $i$ proizvodstvennyh kompleksov - Sustainable development areas, industries and industrial complexes, 3 (59), 39-43. Retrived from http://pdt.vscc.ac.ru/file.php?module=Articles\&action=view\&file=article\&aid=2111 [in Russian]

9. Postanova KMU vid 12.09.2011, 1130 "Pro zatverdzhennja Derzhavnoji proghramy rozvytku vnutrishnogho vyrobnyctva" [Holds the CMU from 12.09.2011, № 1130 "About zatverdzhennya Derzhavnoï prog rozvitku vnutrishnogo virobnitstva"]. (n.d.) zakon2.rada.gov.ua. Retrived from http://zakon2.rada.gov.ua/laws/show/1130-2011-\%D0\%BF [in Ukrainian].

10. Primak, I. (2007). Reinzhiniring: teper bez razrushenij? [Reengineering, now without razrushenyy?]. Upravlenie kompaniej - Management Company, 7. Retrived from http://www.management.com.ua/cm/cm086.html [in Russian].

11. Pshennik, Yu. (2007). Kakoie importozameshhenie nam nuzhno? [Import substitution What do we need?] Ekonomicheskaja hazeta - Economic newspaper, 68 [in Russian].

12. Robson, M., \& Ullah, F. (1997). Prakticheskoe rukovodstvo po reinzhiniringu biznes-processov [A practical guide to business process reengineering]. Moscow: Audit, YuNITI [in Russian].

13. Savchuk, V. (2010). Hhlobalizatsiia ta problemy intehratsii u tsei proces postsocialistychnykh krain [Globalization and problems of integration in the process of post-socialist countries]. Visnyk Ternopilskoho natsionajnoho ekonomichnoho universytetu - Bulletin of Ternopil National Economic University, 5, 22-27 [in Ukrainian].

14. Sytnichenko, V. (n.d.). Stratehia rozvytku mashynobuduvannia na osnovi systemy sbalansovanykh pokaznykiv [Strategy of engineering on the basis of indicators sbalansovanyh. www.ukrtest.com. Retrived from http://www.ukrtest.com/raznoe/publikacii/11.pdf [in Ukrainian].

15. Sosnov, A. (2015). Fenomen shpilki. Inzhiniring uskorit importozameshhenie [Phenomenon studs. Engineering accelerate import substitution]. Poisk. Gazeta nauchnogo soobshhestva - Search. Newspaper scientific community, 39. Retrived from http://www. poisknews.ru/theme/edu/15878/ [in Russian].

16. Stratehiia ekonomichnoho ta sotsialnoho rozvytku Ukrajiny "Shljakhom jevropejsjkoji integhratsii" na 2004-2015 roky [Strategy of economic and social development of Ukraine "Towards European Integration" for 2004-2015]. (n.d.). shron.chtyvo.org.ua. Retrived from http://shron.chtyvo.org.ua/Halchynskyi_Anatolii/Stratehiia_ekonomichnoho_i_sotsialnoho_ rozvytku_Ukrainy_2004-2015_shliakhom_yevropeiskoi_intehratsii.pdf [in Ukrainian].

17. Taraniuk, L.M. (2012). Naukovo-prykladni aspekty procesoorientovanogho upravlinnja na promyslovykh pidpryjemstvakh pry provedenni reinzhynirynghu biznes-protsesiv [Scientific and practical aspects protsesooriyentovanoho management in industrial enterprises during the business process reengineering]. Marketynh $i$ menedzhment innovatsii - Marketing and Management of Innovation, 1, 180-189 [in Ukrainian].

18. Fedulova, L.I. (2006). Perspektyvy innovacijnogho rozvytku promyslovosti Ukrainy [Prospects of innovative development of industry of Ukraine]. Ekonomika i proghnozuvannja - Economics and Forecasting, 2, 58-76 [in Ukrainian].

19. Hammer, M. \& Champi, D. (2009). Reinzhiniring korporatsii: Manifest revoljucii $v$ biznese [Reengineering the Corporation: A Manifesto revolution in business]. Moscow: Mann, Ivanov i Ferber [in Russian].

20. Yakubovskyi, M.M. (2011). Restrukturyzatsiia promyslovosti jak zasib podolannja importnoji zalezhnosti ekonomiky Ukrajiny [Restructuring industry as a means of overcoming import dependence of Ukraine's economy]. Natsionalne hospodarstvo Ukrajiny: teoriia ta praktyka upravlinnia - National Economy of Ukraine: Theory and Practice Management. (pp. 100-112). Kharkiv: In-t ekonom. ta proghnoz. NAN Ukrajiny [in Ukrainian].

21. Werner, B. (1972). Import Substitution and Industrialization in Latin America: Experiences and Interpretations. Latin American Research Review, 7. 95-122 [in English].

22. Blair, J.P., \& Carroll, M.C. (2008). Local economic development. Sage Publications [in English].

23. Bruton, H. (1998). Reconsideration of Import Substitution. Journal of Economic Literature. Retrived from http://econintel.org/Cl705/BrutonlmpSubs.pdf [in English].

24. Cardoso, F.H., \& Faletto, E. (1979). Dependency and Development in Latin America. Berkeley: University of California Press [in English].

25. Davenport, T. (1993). Process Innovation: Reengeneering Work through Information Technology. Boston, MA.: Harvard Business School Press [in English].

26. Dunning, J.H ., Artisien, P., Rojec, M., \& etc. (1993). The Prospects for Foreign Direct Investment in: Eastern Europe. Foreign Invetsment in Central and Eastern Europe. New York: St. Martin's Press [in English].

27. Narula, R., \& Dunning, J.H. (2000). Industrial Development. Globalisation and Multinational Enterprises: New Realities for Developing Countries. Oxford Development Studies, 28(2), 141-167 [in English].

28. Prebisch, R. (1959). Commercial Policy in the Underdeveloped Countries. American Economic Review, 49, 251-273 [in English].

29. Aguilar, R. (1986). Latin American structuralism and exogenous factors. Social Science Information, 25(1), 227-290 [in English].

30. Saantos, T. (1969). The Crisis of Development Theory and the Problem of Dependence in Latin America. Modernization and Development, 21, $42-43$ [in English]. 
О.І. Карпіщенко, О.О. Карпіщенко, Т.В. Ващенко. Реверсний інжиніринг як запорука модернізації промислового виробництва на засадах імпортозаміщення

31. Street, J.H., \& Dilmus, D.J. (1982). Structuralism, and Dependency in Latin America. Journal of Economic Issues, 16(3), 673-689 [in English].

O.I. Карпіщенко, канд. екон. наук, професор, професор кафедри економіки та бізнес-адміністрування, Сумський державний університет (м. Суми, Україна);

0.0. Карпіщенко, канд. екон. наук, доцент, доцент кафедри маркетингу та УІД, Сумський державний університет (м. Суми, Україна);

T.B. Ващенко, канд. екон. наук, асистент кафедри маркетингу та УІД, Сумський державний університет (м. Суми, Україна) Реверсний інжиніринг як запорука модернізації промислового виробництва на засадах імпортозаміщення

у статті розглянуто питання управління бізнес-процесами на промисловому підпиємстві на засадах імпортозаміщення комплектуючих у складі готової продукції, як перехідного етапу до активізації експорту продукції з метою підвищення технічного та наукового рівня виробництва в мінливих зовнішніх умовах сьогодення. Аналіз $і$ прогнозування векторів розвитку підприємства та джерел формування економічно-сталого функціонування доводить необхідність врахування інноваційного підходу при розробиі стратегії ведення бізнесу. Одним з альтернативних напрямів реалізації потенціалу промислових підприємств є варіант впровадження імпортозаміщення саме у виробничій ссрері шляхом витіснення імпортних комплектуючих зі складу готової продукції та їх заміна на вітчизняні. Обгрунтовано доиільність застосування стратегії імпортозаміщення на промисловому підприємстві задля забезпечення виробництва конкурентоспроможної продукції та оптимізації експортно-імпортних операцій. Запропоновано застосовувати практику реверсного інжинірингу для модернізації виробниитва та підвищення конкурентоздатності вітчизняної продукції.

Ключові слова: експорт, імпорт, реверсний інжиніринг, стратегія імпортозаміщення, модернізація виробництва.

А.И. Карпищенко, канд. экон. наук, профессор, профессор кафедры экономики и бизнес-администрирования, Сумский государственный университет (г. Сумы, Украина);

А.А. Карпищенко, канд. экон. наук, доцент, доцент кафедры маркетинга и УИД, Сумский государственный университет (г. Сумы, Украина):

T.B. Ващенко, канд. экон. наук, ассистент кафедры маркетинга и УИД, Сумский государственный университет (г. Сумы, Украина)

Реверсный инжиниринг как залог модернизации промышленного производства на принципах импортозамещения

В статье рассмотрены вопросы управления бизнес-процессами на промьшиленном предприятии на основе импортозамещения комплектующих в составе готовой продукции, как переходного этапа к активизации экспорта продукиии с целью повышения технического и научного уровня производства в меняющихся внешних условиях. Анализ и прогнозирование векторов развития предприятия и источников формирования экономически устойчивого функционирования доказывает необходимость учета инновационного подхода при разработке стратегии ведения бизнеса. Одним из альтернативных направлений реализации потенциала промышленных предприятий является вариант внедрения импортозамещения именно в производственной сфере путем вытеснения импортных комплектующих со склада готовой продукции и их замена на отечественные. Обоснована целесообразность применения стратегии импортозамещения на промышленном предприятии для обеспечения производства конкурентоспособной продукции и оптимизации экспортно-импортных операций. Предложено применять практику реверсного инжиниринга для модернизации производства и повышения конкурентоспособности отечественной продукции.

Ключевые слова: экспорт, импорт, реверсный инжиниринг, стратегия импортозамещения, модернизация производства.

Отримано 25.10.2016 p. 